\title{
NEO-CLIENTELISMO E COOPTAÇÃO NA MANUTENÇÃO DO PODER POLÍTICO LOCAL: Estudo de um caso
}

\section{Elsio Lenardão}

\author{
Professor do Departamento de Ciências Sociais da Universidade Estadual de Londrina
}

\begin{abstract}
Este artigo apresenta os resultados parciais de uma pesquisa realizada em 1995/96 pelo autor, que procurava compreender um conjunto de práticas políticas de tipo clientelistas desenvolvido pelo governo municipal de uma cidade interiorana de porte médio. Tais práticas fazem parte de um 'modelo' político-administrativo instalado pela elite dominante da cidade. Sob sua iniciativa constrói-se um quadro institucional: a) burocrático, que não colabora na criação de canais formais, institucionalizados, de participação e representação dos interesses das classes populares; b) cooptador e autoritário, que busca a todo o tempo tutelar as organizações coletivas dos setores populares, restringido-lhes a liberdade e autonomia. $\mathrm{O}$ fenômeno do clientelismo local é reconstruído a partir de relatos colhidos junto a lideranças populares que estiveram à frente de movimentos sociais no período enfocado.
\end{abstract}

Palavras-chave: Poder local, neo-clientelismo, classes populares.

\section{INTRODUÇÃO}

$\mathbf{E}$ ste artigo resulta de pesquisa realizada sobre um conjunto de práticas políticas específicas que vinham sendo desenvolvidas pelo governo municipal de uma cidade de porte médio do interior paranaense, na sua relação com os movimentos reivindicatórios de moradores da periferia do município durante, o período que vai de 1984 a 1995. Observe-se que são três gestões comandadas pelo mesmo grupo político. Tais práticas reapresentam à arena política antigas formas de clientelismo, personalismo e compadrio, que por tanto tempo marcaram as relações entre Estado e sociedade civil no Brasil. No caso desta cidade, não só grande parte da administração, como também algumas áreas da administração e secretarias, por exemplo as de ação social e obras, apresentavam suas políticas elaboradas, de maneira significativa, conforme diretrizes clientelistas e político-partidárias. Ou seja, prevaleciam nas formulações das políticas públicas locais, as orientações por critérios particulares de ação, bem mais do que por critérios universalistas.

Principalmente a partir da década de 70 o país conheceu o surgimento de novos movimentos sociais que punham em cena a presença e identidade de atores sociais que até então estavam excluídos do espaço político institucionalizado. Mesmo assim, embora se tenha observado a diminuição das práticas clientelistas, é certo que as mesmas continuam em vigor, orientando o fazer político de inúmeras elites políticas locais e regionais.

Assim sendo, buscou-se, enquanto objetivo geral da pesquisa: verificar como se colocavam as relações entre os atores sociais do governo local (representado, especialmente, numa figura singular deste caso, que é o 'vereador do bairro') e dos setores populares (representados nas lideranças dos movimentos reivindicatórios de bairro), já que era nítida a presença de tipos especiais de redes e relações de poder clientelistas e autoritárias, construídas a partir das interações daqueles atores e grupos sociais, envolvidos no caso em questão. Portanto, interessava ver como era possível a presença de um forte processo de domínio em relação aos movimentos populares de bairro, que já fazia parte do 'modelo' político-administrativo da elite política hegemônica na cidade estudada, e que era baseado na cooptação de lideranças populares e no personalismo de alguns 'vereadores do bairro'. 


\section{A Sobrevivência de Práticas Políticas 'Arcaicas'}

Desde a década de 70 os movimentos reivindicatórios dos bairros vêm se colocando, entre os movimentos sociais, como uma das manifestações mais significativas das classes populares. (1) Muitos foram capazes de pôr em questionamento as tradicionais políticas urbanas locais, gestando, às vezes, uma nova correlação de forças com a qual as administrações, doravante, deveriam contar; e outros tantos, são, ainda, capazes de ir legitimando um conjunto de direitos sociais, antes ignorados ou negados.

Por outro lado, boa parte destes movimentos abriu $o$ espaço para o desenvolvimento de 'novas' estratégias de cooptação, revivendo 'novamente' antigas práticas de clientelismo. (JACOBI, 1983, p. 67) Não obstante seja notória a diminuição de práticas desse tipo, vê-se que ainda sobrevivem. Os setores populares, continuam a ser objeto de intensos mecanismos que pretendem seu controle, administração e manipulação, visando a minimização do impacto de suas possíveis intervenções no processo político de gestão da coisa pública.

Dessa maneira, a retomada dos direitos democráticos no pós-ditadura (início dos anos 80 ), não excluiu o desenvolvimento de dispositivos de manipulação política que serviram e ainda servem como contrabalanço à crescente participação política dos setores populares, e à sua relativa, mas significativa, autonomia face ao Estado e partidos políticos propriamente ditos.

De um modo geral têm sido pouco freqüentes os estudos e documentação das variadas formas de manipulação política que são contemporâneas à 'abertura' política da década de 80.

Esta pesquisa almeja a partir da análise num município determinado, revelar e caracterizar a manifestação de um conjunto daquelas práticas, encarnadas especialmente na figura do 'vereador do bairro', nas relações sociais que estabelece com certas lideranças de alguns bairros, com os movimentos populares de reivindicação e algumas entidades

(1) A opção pelo conceito de classes sociais populares justifica-se em razão de que ele facilita a percepção dos agrupamentos a que nos referimos nesta pesquisa, tratando com maior justeza da socialização e articulação dos trabalhadores nos espaços coletivos da sua vida cotidiana, para além do espaço do trabalho formal. Trata-se na cidade em destaque dos pobres urbanos que compartilham condições de vida similares e que montam coletividades no local de sua moradia. (ZALUAR,1985b, p. 36) Quanto a estes últimos, além da identidade gestada pelo fato de ocuparem posições sociais idênticas na produção, identificam-se e unem-se na luta, motivados por interesses comuns que desenvolvem em relação à certas exigências de serviços e equipamentos coletivos, que demandam, especialmente, do Estado. Neste sentido, merece atenção, a consideração de Thompson, onde, sob seu ponto de vista, a classe acontece quando alguns homens, como resultado de suas experiências comuns, sentem e articulam a identidade de seus interesses entre si e contra outros homens, cujos interesses diferem (e geralmente se opõem) aos seus. A experiência de classe é determinada, em grande medida, pelas relações de produção em que os homens nasceram ou entraram involuntariamente. (Apud CARDOSO,1995, p. 50) de representação coletiva onde participam trabalhadores. Intencionando contribuir na construção de respostas à incômoda pergunta: como é possível que vigore ainda, nos tempos da cidade e da democracia, práticas políticas explicitamente clientelistas?

Trata-se do estudo de como a elite política de uma cidade de interior, vem garantindo o acesso e a manutenção do poder político local, mediante métodos que se distanciam (se não contrariam) do espírito central da idéia de democracia, que implicaria, ao contrário, a garantia da autonomia ${ }^{(2)}$ política dos atores sociais participantes na arena política, e a publicização real das estruturas administrativas do Estado.

Importa, portanto, verificar e explicitar que a partir da década de 80, não só os movimentos populares redescobrem novas formas de ação e participação, buscando a construção da cidadania de fato das classes populares, bem como é de extrema relevância verificar que o Estado, neste contexto das relações com os movimentos sociais, além de ampliar seu espaço de atendimento e institucionalização da representação $^{(3)}$ daqueles setores, modifica sua dinâmica de interação com os mesmos, desenvolvendo novas práticas políticas específicas que pretendem a reprodução de seu domínio e a obstaculização da construção da autonomia política das classes populares.

Desvelar um caso particular de ressurgimento de práticas específicas baseadas na cooptação, personalismo e manipulação é parte do objetivo e contribuição desta pesquisa.

De fato, o que se processou desde o ressurgimento dos movimentos sociais das classes populares, como alerta Marcos Novaro, é que as práticas, vínculos e crenças que operam a vida política transbordaram os estreitos limites das formas representativas estabelecidas; é natural, portanto, que ressurjam os velhos e nunca esgotados debates em torno da representação (NOVARO, 1995, p. 78), até porque, conforme indica Paoli, sobrevive mais premente do que nunca, a necessidade e a responsabilidade de se construir um espaço civil cuja legitimidade modifique o autoritário funcionamento do aparato estatal que se conhece de longa data no Brasil. (PAOLI, 1992, p. 498)

É certo que as relações sociais da esfera da política no Brasil historicamente foram matizadas no paternalismo, no clientelismo e no autoritarismo, quando olhadas do ângulo das posições que ocuparam as classes populares e a representação de seus interesses. (ORTIZ, 1995, p. 69) A

\footnotetext{
(2) Neste caso convém observar que a autonomia referida, diz respeito à autonomia política e ideológica dos movimentos e atores sociais face ao Estado, e não a idéia de que aqueles poderiam concretizar seus objetivos e atender suas demandas sem se relacionarem com este e com ele interagirem. Aquela autonomia implica a permanente tensão entre a vivência de seus espaços e a tutela do Estado.

(3) Pressupõe-se o reconhecimento de que a representação é imprescindivel e de que, pelo menos parcialmente, constitui as pessoas públicas, as identidades, vontades e interesses representados, é inclusive um avanço necessário para pensarmos numa ampliação radical da política democrática, pois permite o abandono do assistencialismo, do qual se alimentam, em boa medida, as tradições autoritárias. (NOVARO, 1995, p.89; ver também CHAUÍ, 1989)
} 
observação da recorrência de uma série de experiências de governos estaduais e locais que assentam-se em práticas políticas clientelistas e autoritárias, demonstram a importância de se revelar e compreender como é possível tal sobrevivência. Ou seja, uma parte do maquinismo político brasileiro, ainda hoje, parece basear-se em práticas políticas 'arcaicas'.

Nota-se que há de fato uma certa herança cultural política sobrevivida do coronelismo. Por isso não são estranhos nas práticas corriqueiras do sistema político brasileiro o curral eleitoral, o voto de cabresto, a corrupção eleitoral, o nepotismo, a apropriação do Estado por famílias importantes. Como se ainda tais práticas se orientassem pelo imaginário do coronel, do 'senhor', do mandonismo. O que instiga a curiosidade diante da manutenção de formas sociais de convívio político singulares, que impõem a presença de relações clientelistas nas instituições ditas modernas (AVELINO FILHO, 1994, p 226), levando em conta que sobrevivem poucas reminiscências das condições de vida material como as que deram origem e sustentaram aquelas relações. ${ }^{(4)}$

\section{Procedimentos Metodológicos}

Optou-se por usar como principal fonte de informação e avaliação das práticas políticas que constróem e sustentam o 'vereador do bairro' e as relações clientelistas ali instaladas, os relatos de líderes populares que estiveram atuando à frente de movimentos de bairro ou outros movimentos (partidário, por exemplo), ao menos em parte do período pesquisado. $\mathrm{E}$, mais, privilegiou-se a entrevista com aquelas lideranças que postaram-se crítica e autonomamente em relação às gestões municipais que servem de pano de fundo ao período em questão, e à prática de cooptação permanente que desenvolve o 'vereador do bairro'.

São, portanto, lideranças que não se sujeitaram, às práticas de clientelismo e à influência personalista do 'vereador do bairro'. Inclusive, em razão disso, algumas foram perseguidas, policiadas e são, ainda hoje, quase todas, estigmatizadas na cena política 'oficial' da cidade. E, justamente por essas razões, são fontes qualificadas para uma avaliação crítica daquelas práticas.

Foram feitos contatos pessoais (várias conversas informais) e entrevistas com doze lideranças dos bairros que circundam especialmente dois bairros (Bairro '1' e Bairro ' 3 '); três entrevistados não residem exatamente nessas áreas, embora tivessem acompanhado de perto e vivenciado o fenômeno estudado. Fica para outra ocasião as interpretações dos próprios 'clientes' daquelas práticas e as dos políticos, seus condutores.

Dada a forte expressão dos fenômenos comentados na pesquisa na área próxima àqueles bairros, centrou-se a

\footnotetext{
(4) Quanto a essas condições, são muito ilustrativos os capítulos III, IV, VII do livro Raízes do Brasil, de Sérgio Buarque de Holanda. Ele, por exemplo, reconhece que o patriarcalismo e o personalismo são traços de práticas políticas fixados entre nós por uma tradição de origens seculares, que ainda influenciam e ajudam a desenhar nosso maquinismo político. (HOLANDA, 1988, p. 47)
}

análise a partir destes locais, não obstante, é certo que mais duas áreas (Bairro '6' e Bairro '9') conhecem a presença do 'vereador do bairro' e as práticas políticas que o acompanham.

Foi dada ênfase à análise qualitativa destes depoimentos, onde se pôde buscar, além das informações mais particulares sobre as práticas políticas especificas ali desenvolvidas e suas implicações, o esclarecimento de como se coloca a mediação entre sujeitos, a estrutura e o processo social, principalmente, por intermédio da categoria classes populares. A escolha dos entrevistados foi feita a partir do próprio conhecimento e experiência do autor sobre os fatos e os personagens envolvidos, buscando selecionar as pessoas cujas atitudes expressas revelavam maior significação para os fins da pesquisa. Obviamente, para preservar suas privacidades, os entrevistados solicitaram a omissão de seus nomes, que foram substituídos por outros sinais indicadores. O mesmo tratamento foi utilizado quanto aos personagens eventualmente citados e localidades de que trata a presente pesquisa. Segue-se deste modo a indicação de Bruce Cohen de que

os sociólogos devem estar certos de que não estão causando nenhum mal aos indivíduos pesquisados. Devem tratar a informação fornecida (...) de forma confidencial. Não devem enganar os investigados: devem dar-lhes informações precisas sobre a natureza do estudo. (...) Além disso, os sociólogos devem precaver-se contra possiveis danos aos indivíduos pesquisados. (COHEN, 1980, p. 13 e 17)

Dos conteúdos das entrevistas, esta pesquisa detevese, particularmente, sobre os juízos formulados pelos entrevistados a respeito das práticas do clientelismo local. Relevou-se a direção (juízo positivo ou negativo), a intensidade e a freqüência desses julgamentos.

\section{Os Novos Movimentos Sociais}

Desde a metade dos anos 70 o regime militar que se instalou em 1964 revelava sinais de que o modelo econômico adotado estava se esgotando, e a forma violenta de domínio da qual fazia uso, apresentava os mesmos sintomas. ${ }^{(5)}$

No bojo da crise do modelo que se acentuava a partir do final dos anos 70 , ressurgia o protesto dos setores populares urbanos. Por um lado retomava vigor o sindicalismo operário através de grandes movimentos grevistas (greves operárias no $\mathrm{ABC}$ Paulista) e de uma renovação na postura diante do legalismo Celetista, que atrelava por demais as entidades sindicais ao controle do Estado desde Getúlio. Este novo sindicalismo renascia criticando e colocando-se autônomo quanto ao sindicalismo tutelado pelo Estado. Por outro lado, as classes populares

\footnotetext{
(5) Este texto não se deterá na explicação do processo de esgotamento que sofre o regime militar. Para uma introdução à compreensão deste fenômeno ver, por exemplo: LINHARES, 1996, p. 301-340.
} 
urbanas organizavam-se em novas formas de movimentos sociais que surgiram nas lutas por condições melhores de vida nas cidades: o Movimento do Custo de Vida, protestos públicos realizados por moradores da periferia e por favelados, movimento por creches, organização dos moradores dos bairros em Associações, etc.

De qualquer modo, esses movimentos sociais instalavam na ordem do dia novos atores sociais, que no geral, pleiteiavam a ampliação dos direitos de cidadania, reformulando, inclusive, a idéia de cidadania restrita comum ao receituário liberal clássico: quer dizer, cidadania como os direitos e obrigações políticas de cada indivíduo. (LINHARES, 1996, p. 342). A ampliação do conteúdo da cidadania para os grupos sociais que compunham estes novos movimentos, implicava a inclusão de uma extensa lista de direitos que ultrapassam em muito o simples exercício do voto. $\mathrm{O}$ que interessa mais nesta pesquisa, é perceber que para esta renovada concepção de cidadania, orientadora de boa parte daqueles movimentos, a mesma se punha como produto de uma relação de poder composta de pressões e contrapressões, produzindo imagens simbólicas dinâmicas de auto-reconhecimento dos grupos sociais e dos seus projetos. (LINHARES, 1996, p. 342)

Neste contexto, desenvolveram-se variadas formas de auto-organização dos setores das classes populares: associações profissionais e de bairro, de consumidores, sindicatos. E estas novas entidades da sociedade civil organizada (...) assumem o papel de interlocutores legítimos com o Estado (e mesmo os partidos), mostrando que os mecanismos clássicos de representação - o indivíduo e seu voto-estavam em crise. (LINHARES, 1996, p. 342)

No geral, os novos movimentos sociais urbanos eram organizados por moradores pobres de bairros periféricos das médias e grandes cidades brasileiras, expressando o descontentamento e reivindicações destes em relação à forma de ocupação do solo urbano, quanto ao acesso a serviços públicos coletivos (como fornecimento de água, rede de esgoto, rede elétrica, saúde, transporte coletivo) e, especialmente, problemas vinculados à exigência em torno dos déficits de moradia popular.

Parte considerável das Ciências Sociais no Brasil considera que os novos movimentos sociais, surgidos na década de 70 , significavam a consolidação de maneiras alternativas efetivamente válidas e reconhecidas, das classes populares colocarem suas lutas (demandas e reivindicações), a partir do local onde habitavam, questionando principalmente as formas de intervenção do Estado autoritário no meio urbano. Assim sendo, eles foram responsáveis pela ampliação da presença de setores das classes populares na vida política brasileira, principalmente dos movimentos reivindicatórios dos bairros pobres.

Quanto às possibilidades, limites e contradições dos novos movimentos sociais que o Brasil vem conhecendo desde a década de 70 , e sua relação com a construção da cidadania, podem-se, simplificadamente, destacar duas posições polares, que se distinguem pela diferenciação que denotam aos significados desses movimentos.

A primeira delas desenvolve suas observações relevando o caráter intermitente, cíclico e defensivo dos movimentos. Como observa Paoli, tal posição considera a ausência de unidade de seus interesses, o imediatismo e corporativismo de suas ações como um grande impecilho à necessidade de generalizar suas lutas e conquistas, de maneira que não se universalizam como perspectiva de um outro horizonte político para a sociedade. (PAOLI, 1992, p. 503; ver também JACOBI, 1990). Além do que, esses movimentos recusariam os tipos de representação política instituídos, confirmando sua dificuldade para a formulação de projetos de maior abrangência.

Embora, na raiz do discurso antiEstado presente aqui, esteja o reflexo

do corte que estimula a emergência de diversas [outras] formas de resistência, colocando permanentemente, mesmo após as alterações políticas que já apontavam certo processo de redemocratização da sociedade, a tensão existente entre o caráter de resistência do movimento social e sua institucionalização. (JACOBI, 1990, p. 34-5)

No período (década de 70), o Estado era identificado como o agente da 'ordem' que oprimia, reproduzia a carência nos bairros, mantinha o controle dos trabalhadores nas fábricas e que forçava o silêncio do conjunto da sociedade.

Importa, porém, para essa interpretação, salientar que a maioria das práticas reivindicatórias destes movimentos sociais não se pautaria na perspectiva de transformar a sociedade, incutindo-lhe um sentido novo. Na verdade, essas práticas pouco afetariam a esfera política dada.

De qualquer maneira, as interpretações 'pessimistas' quanto ao papel dos movimentos na mudança social não ignoraram que as lutas levantadas por eles representariam uma das formas de pressão permanente dos setores populares sobre o Estado na busca de respostas concretas às suas demandas. Obviamente que tais lutas se subordinavam aos fluxos e refluxos das diversas conjunturas e também às lógicas próprias de funcionamento pautadas por um maior ou menor enquadramento institucional.

Por outro lado, uma segunda interpretação considera que dentro do processo político mais amplo, o crescimento e consolidação dos movimentos sociais das classes populares leva ao reconhecimento crescente daqueles, como interlocutores válidos e legítimos dos interesses destas classes. Neste mesmo processo, mudam, relativamente, o discurso e certas práticas dos órgãos públicos que passam a incorporar paulatinamente as demandas da população dos bairros periféricos.

Assim, a presença do coletivo, ou da cidadania coletiva, como aponta Paoli (1992), gera uma nova qualidade na idéia de participação na gestão da coisa pública. E ainda, segundo observação de Pedro Jacobi, aqui a representação não resume todo o esforço de organização, mas configura uma parte de um processo onde os moradores criam as condições para influenciar na dinâmica de funcionamento de um órgão do Estado. (JACOBI, 1990, p. 38)

Destaca-se aquela face dos movimentos sociais 
populares onde a entrada em cena de novos personagens funda o início de uma sociabilidade ancorada na solidariedade de classe e através da qual as classes populares passam a fazer parte da cena histórica, como atores que não se limitam a papéis já fixados por outras classes, mas como sujeitos que, por iniciativa própria desenham a cena de sua ação.

Verifica-se, na verdade, certo avanço social, levando à inscrição das demandas e práticas dos setores populares numa nova noção de direitos, retirando-as do campo das reclamações e reivindicações. Tal avanço constitui-se em elemento fundamental para a superação do ethos autoritário presente no Estado brasileiro. Objetiva pois, especialmente, a interferência nas estruturas institucionais do Estado, permitindo avanços no plano dos sistemas de representação, cristalizando-se em novas formas de manifestação de identidades coletivas que carregam consigo as contradições entre a conquista de uma cidadania ampliada e a permanência de uma situação de exclusão. (JACOBI, In: SADER, 1987, p. 19)

Há, nesta perspectiva, a potencialidade de consubstanciação de nova práticas que possam configurar o papel de interlocutores aos movimentos, que propiciem $o$ seu reconhecimento pelo Estado, e que promovam, por sua vez, os espaços de atuação e práticas destes movimentos no sentido de disseminar concepções mais avançadas de gestão pautadas por formas de efetiva descentralização do poder. (JACOBI, In: SADER, 1987, p. 22)

Note-se, porém, que a presença de diversos movimentos reivindicando maior participação social, questionando o discurso 'participacionista', tem revelado algumas contradições, como a dificuldade dos governos municipais em propor uma incorporação efetiva da população na tomada de decisões de seu interesse.

Ocorre que, não obstante o papel fundamental que os movimentos sociais populares vêm desempenhando na abertura e consolidação de espaços de participação e representação dos interesses populares junto ao Estado, ressurgem práticas políticas específicas, iniciadas muitas vezes, por grupos políticos conservadores que estão na direção dos governos municipais, baseadas na cooptação, no personalismo e na tentativa de manipulação daqueles próprios movimentos. Certamente os interesses estratégicos desses grupos referem-se à reprodução do seu domínio e à obstaculização da construção da autonomia política das classes populares.

É este 'ressurgimento' o objeto de estudo desta pesquisa, que vai procurar revelar em seguida, como o Estado (aqui representado por um governo municipal) pós-ditadura militar também foi capaz de renovar seus mecanismos de dominação política frente a setores das classes populares que fortaleciam sua autonomia e capacidade política crítica.

\section{CLIENTELISMO E COOPTAÇÃO NA MANUTENÇÃO DO PODER POLÍTICO LOCAL}

\author{
(Quadro Político-Institucional geral)
}

De acordo com Jacobi, não obstante tornar-se cada vez mais difícil grupos políticos dominantes reproduzirem à vontade, através do Estado, práticas pautadas nos esquemas populistas, sua reemergência não é improvável; dada a presença e a permanência de lideranças tradicionais à frente dos esquemas clientelistas passiveis de reeditar cenas de filme já visto. Em sua avaliação, basicamente, a retomada destas práticas ou sua rejeição, está na dependência dos avanços do movimento social quanto ao seu nível de politização e de desenvolvimento de uma consciência crítica. (JACOBI, In: SADER, 1987, p. 21)

Tal opinião centra o enfoque na importância que determinados quadros institucionais (tipos de partidos, de lideranças, canais de participação, de movimentos sociais e de leis), têm para a reprodução e sustentação de esquemas baseados no clientelismo.

Também nesta pesquisa, houve o privilegiamento da apresentação de um destes quadros que facilitam a sobrevida daqueles esquemas. Embora trate de situações restritas a uma localidade (cidade de porte médio interiorana), é possível compará-las às de outros quadros já analisados, encontrandose inúmeras similaridades e aproximações que permitem inferir que a presença de certas situações institucionais (autoritarismo, burocratismo e elitismo) tornam mais favoráveis a reprodução do clientelismo. (Ver: DINIZ, 1982a e 1982b; ZALUAR, 1985a e 1985b; AVELINO FILHO, 1994)

Certamente há também outros elementos sociais e culturais que dão sua contribuição, gestando relações sociais facilitadoras de práticas políticas clientelistas. Apenas para indicar um exemplo, no caso estudado, a Igreja, através de seus movimentos pastorais, tem relevância destacada. Inúmeros líderes de comunidade que em seguida tornar-seão 'vereadores de bairro', ligados ao clientelismo, passaram antes pela condição de lideranças religiosas, o que provavelmente influenciou deveras sua idéia acerca do que é a política, a 'comunidade', e como se faz política na e para a 'comunidade'. Especialmente se levar em conta uma formação religiosa que destacava o 'serviço' à comunidade, a doação e a caridade (como atributos fundamentais da vida social do cristão), conforme pode-se perceber nas entrevistas realizadas.

Da mesma forma esses valores participam de parte considerável da instrução do comportamento dos moradores que compõem a clientela daquelas práticas. Do exemplo acima, tem-se uma idéia da importância de se levar em consideração, na busca de uma compreensão mais totalizadora do fenômeno clientelismo, como o quadro geral institucional que o circunscreve, articula-se com aspectos culturais e simbólicos particulares, certamente compondose, num plano ideológico, com um sistema específico de valores e de padrões de comportamento cotidiano. (Ver 
DaMATTA, 1996)

Por outro lado, Victor Nunes Leal observou que dentro das situações sociais que podem auxiliar no desenvolvimento de práticas clientelistas está a pobreza do povo, seu atraso cívico e intelectual. (1986, p. 258)

Comentando a existência do clientelismo em bairros da cidade do Rio de Janeiro, Alba Zaluar destacou que a fonte dele está muito menos na ignorância política dos moradores pobres, do que na imensa reserva de necessidades e carências abertas à manipulação dos políticos oportunistas. (ZALUAR, 1985b, p. 62)

Alguns depoimentos colhidos para esta pesquisa atestam o considerado acima:

(...) realmente havia muitas demandas nestes bairros que foram loteados no início dos anos 80; o pessoal ia lá auto-construir, devagarinho, suas casas, e aí não tinha nada mesmo. Não tinha asfalto, não tinha esgoto, não tinha nada. (Diretor de Associação de Moradores)

Pro povo aquilo era uma salvação. Por exemplo, você tava às vezes, na fila do ônibus, e começava a falar, a questionar. Sabe, algumas senhoras, o pessoal mais antigo achava inquestionável o caso do (...) [vereador ' $A$ '], por que ele deu remédio:

- Ele me dá remédio.

Daí você conversava com a pessoa:

- Mas olha, esse remédio tem lá no Posto.

- Não. Esse remédio é ele que compra.

$E$, realmente, se você for ver, para essa senhora é uma vantagem. Ela conseguiu um remédio caro, uma coisa cara. [Ex-integrante de Comunidade Eclesial de Base: C.E.B. do Bairro '1']

Esta pesquisa reconhece a importância dos elementos culturais (simbólicos) e sociais sempre presentes na composição do fenômeno do clientelismo. Porém, manterse-á circunscrita à tentativa de descrever o quadro institucional geral que abarca as práticas clientelistas destacadas na cidade estudada, buscando caracterizar, em certos pormenores, o fenômeno.

Em vários autores brasileiros é reconhecida a presença atual do clientelismo no quadro da política brasileira, a despeito da industrialização, da emergência dos novos movimentos sociais e das alterações legais que institucionalizaram canais formais e efetivos de participação dos setores populares na gestão do Estado. (AVELINO FLLHO, 1994; DINZZ, 1982b; DROULERS, 1989; ORTLZ, 1995; ZALUAR, 1985a e 1985b; SADER, 1987)

De fato, a impressão que há não é a de que o fenômeno esteja de volta, mas sim a de que ele nunca deixou de existir. Como aparece recorrentemente, é bem provável que o correto seja considerá-lo como um dos aspectos que compõe a vida política brasileira, um continuum, e não um adendo a ela.

Em sua especificidade (de modalidade de atuação política), o clientelismo manifesta-se a partir de um sistema de lealdades, que se estrutura em torno da distribuição de recompensas materiais e simbólicas, em troca de apoio político. (DINIZ, 1982b, p. 23)

O passar do tempo imprimiu modificações na estruturação do fenômeno e nos seus mecanismos de reprodução, embora baseie-se ainda no favor, no personalismo, na cooptação e na informalização da política.

No Brasil, onde as taxas de crescimento urbano são bem mais elevadas, sai-se de uma situação de clientelismo na qual a subordinação pessoal nascia da total dependência econômica, para uma situação de clientelismo político moderno, onde o político torna-se um dos intermediários no acesso aos recursos do Estado. Essa função de intermediario é cada vez mais importante, é a do 'broker' dos anglo-saxões, literalmente o corretor, esse personagem do mundo urbano e da esfera política moderna, que desconta no tráfico de influência para ter acesso a bens do Estado, uma dessas figuras que bem poderia ser a do famoso despachante da sociedade brasileira: o intermediário obrigatório nas relações complicadas que o cidadão enfrenta com um Estado excessivamente burocrático. Essa função de intermediário passa, então, e cada vez mais, pelos canais da política. Essas formas de clientelismo modernizado são bem diferentes do clientelismo tradicional. A sua esfera de influência é mais extensa e implica o controle dos canais de organização coletiva, sindicatos ou associações de bairro. (DROULERS, 1989, p. 140)

No município estudado essa extensa esfera de influência aparece com nitidez, apontando para um estilo de política que já dura 12 anos (1984-96), e que é marcado pelo autoritarismo e pela busca permanente de cooptação e controle dos movimentos sociais populares.

A partir dos relatos das entrevistas revelam-se sinais que indicam a tentativa de cooptação que vai para além das lideranças populares e de Associações de Moradores de Bairro. Esses mesmos relatos apontam prática semelhante em relação ao sindicato dos servidores municipais e à escolha (pela prefeitura) seletiva dos componentes do Conselho Municipal de Saúde e o controle firme das ações da Federação das Associações de Moradores da cidade.

O grupo de depoimentos que segue abaixo explicita os detalhes do comportamento que vem desenvolvendo o grupo político que detém o controle do executivo municipal e da maioria do legislativo, desde 1984.

Sobre a relação da prefeitura com o Sindicato dos Servidores: 
(...) foi um processo marcante, porque foi um processo de discussão política. Teve um grupo de servidores que começaram a fazer um processo de criar um sindicato, e criaram. Começaram a questionar a prefeitura, a politizar e tudo mais. Teve uma greve feia aqui. Foi no (...) [prefeito do período]. Mobilizaram todo o pessoal, teve uma discussão muito boa. Aí, eles [a prefeitura] começaram a perseguir o pessoal. Eles fizeram um processo assim de cassação mesmo. Matou de uma forma que hoje não existe nada. Prá você ter uma idéia, o servidor público de (...) [da cidade] está há dois anos recebendo o salário parcelado, em duas, três vezes, e ninguém faz nada. Nem se questiona. (Depoimento colhido em maio de 1996. Fundadora e ex-integrante da P.J.: Pastoral da Juventude; ex-diretora da Associação de Moradores do Bairro '2'; ex-diretora da Federação de Associações de Moradores.)

Quanto ao controle sobre a Federação das Associações, o relato abaixo demonstra como a prefeitura agia:

(...) [o executivo municipal] tentou implantar a questão da criação da Associação de Moradores. Era uma forma de organização nos bairros. Mas, eram todas cooptadas. Por exemplo, dava infraestrutura, dava camiseta, boletins, esses negócios. Fazia indiretamente, né? Mas faziam. Os candidatos eram os cabos eleitorais deles, o pessoal que trabalhava prá campanha dele, o pessoal da linha deles. Conseguiram umas 15, mas boa parte era meio fantasma, só burocrática. Mas era bom, porque compunham a Federação das Associações, também criada por eles, guiada por eles. (Exdiretora de Associação de Moradores; ex-integrante da P.O.: Pastoral Operária)

Nos relatos é freqüente a observação de que a prefeitura, no período enfocado, sempre desenvolveu uma aproximação junto às lideranças populares que despontavam, procurando cooptá-las ao esquema clientelista do grupo político dominante:

Eu lembro que teve uma época prá saí vereadores, eu não lembro qual das eleições mas, convidaram o ... [liderança ligada à P.J. na época] prá sair vereador, eles do PMDB. Tentaram comprar [a liderança] prá sair a vereador dizendo prá ele que bancavam a campanha dele, etc. Tem um outro amigo da gente que, inclusive ele saiu candidato na última gestão, junto com [candidato a prefeito], que é o (...). Até, nessa época, ele participava com a gente, só que ele não era muito aprofundado na situação. Ele defende... $O(\ldots)$, ele não era filiado ao Partido [PT], mas tinha uma aproximação muito grande com a gente. E, ele tem uma influência muito grande, porque ele canta, puxa os cantos na igreja, tem violão, qualquer lugar que chega toca uma viola e canta. Ele era prá sair candidato pelo PT. E, na última eleição ele saiu candidato com o (...) [último prefeito eleito] $(P M D B)$ e saiu decepcionadíssimo [não foi eleito, inclusive]. (Ex-diretor de Associação de Moradores, membro da P.O. e ex-candidato a vereador na cidade)

A escolha e cooptação de lideranças aparece sempre, nos relatos, como uma condição essencial para o funcionamento do clientelismo local, em razão de que a montagem do esquema clientelista, de sua rede de funcionamento, depende muito de mediações pessoais entre a prefeitura e a 'comunidade' e as entidades coletivas das classes populares.

A extensão do controle das iniciativas políticas, como já foi observado, pode ir até onde houver interesses das classes populares em jogo:

Você pode pegar aqui o Conselho de Saúde [municipal] que eles formaram. Eles pegaram uma pessoa da igreja, mas uma pessoa ligada a eles. Funcionário deles. Eles não pegou, assim, um coordenador da Pastoral dos Imigrantes, da P.O. Não. Eles escolheram uma pessoa ligada a eles, que trabalha para eles, prá trabalhar no Conselho. (Líder comunitário, ligado à Pastoral dos Migrantes e P.O. da Região do Bairro '3’)

Selecionar, cooptando, lideranças para participarem da rede de influência e de clientela instalada na cidade, implica por sua vez a 'eliminação' de lideranças alternativas: $\mathrm{Na}$ verdade, liderança aqui, desde o (...) [prefeito do período aludido ] até agora, sempre foi assim, quem concorda com eles é convidado para participar. (Coordenador da P.O., exdiretor de Associação de Moradores)

Tratando ainda do quadro político institucional geral do município, que circunscreve e inclui o clientelismo local, nota-se que no plano político referido não se encontram canais institucionalizados previstos de participação popular e/ou de recepção de suas demandas, facilitando e estimulando a procura de alternativas informais e individualizadas de atendimento. O que, indubitavelmente, cria laços de dependência e instiga à prática do favor e da dádiva:

Há filas de gente na prefeitura. Ao invés de ser, por exemplo, Secretaria de Ação Social, eles los moradores] procuram a Câmara de Vereadores. Você pode passar prá você ver a fila de gente em frente à Câmara. É comum. O pessoal vai procurar eles [os vereadores] lá na Câmara. (Ex-diretor de Associação de Moradores)

Contígua à ausência de canais e espaços de participação e representação dos interesses dos setores populares está a presença de iniciativas da prefeitura em 
fazer a seleção dos reclamantes e das reivindicações, levadas até ela pelos moradores dos bairros pobres:

Chegava lá na prefeitura, o cara que cuidava..., chamava Assuntos Comunitários, a Secretaria, esse cara, nunca me esqueço desse cara. Ele falava assim prá mim:

- Você é representante do quê?

Eu não representava nada. Primeiro ele falou:

- Você sabia que vocês tem o presidente da Associação de Moradores, assim, assim,...

Enfim, ele dava a lista e eu dizia:

- Mas olha, esse pessoal não tá ouvindo essa queixa...

Daí ele dizia:

- Olha, aqui, nós não recebemos, nós não podemos registrar nada, aqui.

Enós levamos um abaixo-assinado, e ele disse que não podia registrar nada. (Ex-integrante de C.E.B.: Comunidade Eclesial de Base)

\section{O 'Vereador do Bairro'}

No município em foco, destaca-se a maneira peculiar que caracteriza o exercício do poder político local ${ }^{(6)}$, especialmente a relação entre parte do legislativo (alguns vereadores) e a população moradora da periferia da cidade.

Em primeiro lugar há um loteamento dos bairros da cidade entre os vereadores pertencentes ao partido que dirige o executivo. Há uma estrutura marcada pela divisão de áreas de influência, delimitando o poder de diferentes vereadores nas várias circunscrições, onde se firmam clientelas eleitorais locais. Pelos depoimentos, tal divisão coloca-se desde 1984, quando se consolidou no poder um grupo político ligado ao antigo MDB, e que mantinha até o final de 1995 o domínio político na cidade. Porém essa divisão de áreas de influência, podia contemplar vereadores que não eram daquele partido.

Em época de eleições, por exemplo em 88, e a gente viu isso mais em 92, eles tinham brigas assim..., de um candidato no outro bairro. Tal região era a região de tal candidato.

- Era minha região. Era território meu.

Inclusive o próprio pessoal do bairro era acostumado com essa idéia. (Ex-integrante da P.O. na região do Bairro '4'/Bairro ' 1 ')

Até as crianças sabem que o (...) [vereador ' $B$ '] éo vereador do (...) [bairro '3']. (Integrante da P.O. da região do Bairro '5'. Ex-diretor de Associação de Moradores da região)

\footnotetext{
(6) A expressão poder local refere-se à idéia de espaço delimitado e à formação de identidades e práticas políticas específicas embora a referência a uma espacialidade particular, o poder local não se resume a ela. Espaço, neste caso, diz respeito à indicação, em forma de abstração, da presença de relações sociais privilegiadas entre atores e grupos sociais que interagem na disputa e na cooperação. (FISCHER, 1991, p. 88; ver também LEDRUT, 1981)
}

No município pesquisado, o funcionamento do esquema clientelista instalado depende essencialmente da mediação política e da cooptação de líderes e movimentos de reivindicação, promovidas pelo 'vereador do bairro' .

Vê-se que é frequiente nos relatos, a insinuação, a desconfiança de que o mapeamento e distribuição dos bairros da cidade entre alguns vereadores deriva de iniciativa do próprio grupo político que comanda o executivo municipal.

E mais. Crê-se que tal iniciativa prevê ainda 'fazer' vereadores para essas regiões. Quase sempre cooptando lideranças ligadas ao meio popular, com certa ascendência junto aos moradores de determinada região. Quer dizer que o poder público local (o grupo político hegemônico na prefeitura) desenvolve iniciativas (estimula a própria mediação pessoalizada) que favorecem bastante a instalação do clientelismo e da personalização das relações políticas nascidas entre o Estado e as classes populares daqueles bairros.

Eles pegaram as pessoas que mais despontavam nos bairros. Tanto que o pessoal [antigos lideres comunitários, religiosos], ou foi trabalhar na prefeitura como funcionário ou algum se elegeram vereadores. Um exemplo, em (...). [Bairro '5'] eles pegaram o coordenador do Grupo de Jovens, que era o (...)[cita o nome]. Tinha dez anos de Coordenador de Grupo de Jovens. Daí, eles pegaram ele de candidato e o grupo de jovens saiu na rua fazendo campanha prá ele. (Integrante da P.J. e P.O. desde 1985 na cidade)

$O$ (...) ['vereador do Bairro I'] trabalhou no começo dos anos 80 na construção da Paróquia da região. Ele ajudou bastante na sua construção. De maneira espontânea. Ele era de lá. A prefeitura se aproximou dele, viu que ele tava despontando como liderança, já trabalhou em cima dele. Aí teve a campanha dos banheirinhos, que foi um negócio ligado junto com a Paróquia. E quem era o coordenador? Era o (...) ['vereador do bairro I']. Aí, ele fazia os mutirão. E o nome dele foi se projetando. (Ex-integrante da P.O. e de C.E.Bs. na região do Bairro ' $l$ ' de 1987 a 1990)

O papel da representação política, aqui, é reduzido a uma visão clientelista e de favoritismo. A engrenagem política do município funciona articulando executivo, secretarias e 'vereador do bairro'. Portanto sempre através da mediação personalizada e não de forma impessoal, segundo padrões universalistas (mecanismos formais e/ou canais institucionais).

É quase que um subsistema político, para além do institucional e formal, constituído principalmente pelos secretários das pastas prioritárias (saúde, obras e Assuntos Comunitários), o 'vereador do bairro' e a liderança local, onde se processam mensagens e demandas que, com a influência e mediação do 'vereador do bairro', serão transmitidas ao órgão competente da prefeitura. 
Nesse ponto, era claro assim, a questão que esse vereador ele é daquela... [região]. Ele é que faz. Aquilo que ela falou de quando foi lá prá prefeitura, a prefeitura falou:

- Não! Vocês tem o vereador tal. Pede pro vereador, que o vereador de vocês vem aqui.

Já era delimitada a área deles." (ex-participante de C.E.Bs. da região do Bairro 'I' de 1988 a 1990)

Comentando a política clientelista moderna, George Avelino Filho diz que ela é

mais competitiva que sua antecessora e suas relações tendem a ser muito mais frágeis, já que mais 'instrumentais'. Ela sobrevive a partir da sua capacidade de substituir os antigos laços de lealdade pessoal pela oferta de beneficios materiais, os mais individuais possiveis, de maneira a evitar conflitos e maximizar o seu arco de influência eleitoral. O patrono moderno é o broker [corretor, despachante]. E seu poder depende das suas habilidades em operar como intermediário entre sua clientela e os recursos públicos". (1994, p. 227)

Observa-se que o poder e popularidade do 'vereador do bairro' decorre de seu poder político e prestígio social. Quer dizer, da capacidade de intervir diretamente no aparelho administrativo municipal, distribuir pessoalmente, recursos e serviços, 'ajeitar' um emprego, 'adiantar' um atendimento médico pelo S.U.S., etc. Esse mesmo prestígio e capacidade, obviamente que em proporções menores, ele vai transferir para pessoas chave na comunidade, sua clientela. Às vezes, um diretor de Associação de Moradores, ou um líder religioso de expressão, ou, se necessário, ele mesmo promove a construção de uma liderança sua, colocando-a como intermediária na distribuição de alguns serviços da prefeitura: organizadora da horta comunitária, responsável pela distribuição gratuita de leite, recolhedora dos pedidos de escritura de terrenos, etc. Esta liderança, 'amiga' próxima do 'vereador do bairro' faz o papel de intermediária entre os moradores e os políticos, e estes (na figura do 'vereador do bairro'), entre as lideranças e a prefeitura (executivo, secretarias, Cohab, etc.)

Desta maneira, o que deveria ser um direito: o atendimento às necessidades em termos de serviços públicos e uma prerrogativa da cidadania: a existência de canais e mecanismos formais e impessoais de relação política, tornamse possibilidades sujeitas à concessão e à barganha. Práticas típicas do clientelismo, inscritas num esquema informal de ligação mediada entre a comunidade e o governo municipal. (DINIZ, 1982a)

Quando se colocam demandas concretas, como questões de abastecimento de água, limpeza pública, segurança e policiamento, ou ainda, iluminação, calçamento de ruas, oferta de escola e hospitais, abre-se espaço para o acionamento de vínculos personalistas, como forma de encaminhamento de reivindicações destas questões.
Era bem assim: tudo o que a Associação de moradores reivindicava ou pedia, era aquele canal feito pelo vereador. A gente pedia, o (...) [vereador "C"] era o vereador da vila, aí ele colocava lá na audiência lá, como ele tava pedindo aquilo. Não tava nem preocupado que era um pedido da Associação de Moradores tal, que ele tava levando. Não! Ele dizia que era dele. (Exdiretora da Associação de Moradores do Bairro '2')

Agora ele tá fazendo, e você vê que é uma prática que continua, a questão das escrituras da casa. (...) A Associação solta um panfletinho dizendo que quem não tem as casas regularizadas é prá procurar a prefeitura. Daí, essa prefeitura é o (...) [vereador ' $B$ '].O (...) [vereador ' $B$ '] dá as escrituras. Mas, na verdade ele não dá. Ele encaminha. Porque eles tem a Assessoria Jurídica da prefeitura, e eles, em nome do (...) [vereador ' $B$ '] ... O(...) [vereador ' $B$ '] manda lá, os documentos, faz o pedido, e eles dão de graça a escritura prá pessoa. Porque se não, ele teria que procurar um cartório práfazer esse papel. Daí, ele 'quebra' pro cara, né? Fica mais barato. (Fundador e ex-integrante da P.J. na cidade, integrante da P.O. da região do Bairro '3')

O vereador de bairro aproveita as oportunidades para distribuir pessoalmente obras e serviços públicos, como dádiva sua, como benemerência, generosidade. De fato, o que se objetiva é a futura gratidão, em forma de voto, preferencialmente.

(...) ele [o vereador ' $B$ '] é defendido no (...) [bairro '3'] por isso, porque ele é 'o vereador das caixad'água', ele que entregava. Caixas d'água conseguidas com verba do Estado. Só que ficou um negócio assim, como se ele trouxe as caixa d'água e entregou. (Morador do Bairro '5', ao lado do Bairro ' 3 ' e participante do movimento de P.O. da região)

(...) a questão das telha... Deu o vento, no outro dia ele passou nas casas anotando nome e, ele veio da prefeitura. É lógico: se destelhou a casa do cara, o outro traz telha... Você acha que o cara vai recusar? Lógico, ele tá adorando. E, então, ele ficou com o nome feito aí. (Ex-integrante da P.J. de 86 a 89. Já disputou a direção da Associação de Moradores da região do bairro '3' com chapa autônoma em relação à prefeitura) 
Ele [o 'vereador do Bairro l'] vai realmente visitar as pessoas. Tem um destelhamento? Ele vai, leva a telha, e ele coloca a telha. E, ele é excelente pedreiro. Traz na casa. Tem caso lá, que ele ajuda a construir. Daí, faz a escritura. Faz mutirão em que ele organiza, que ele sabe..." (Ex-membro de C.E.B. no Bairro '1', de 88 a 90)

Outro elemento básico na constituição de relações políticas clientelistas é o favor. O favor gera uma reciprocidade direta e uma hierarquia entre devedor e receptor. Quem recebe um favor fica em débito com aquele que o prestou, devendo retribuí-lo na primeira oportunidade. $\mathrm{Na}$ relação clientelista, de fato, o favor sempre se instala como uma armadilha, através do qual o político tenta prender o morador-eleitor. Examine-se o relato que segue, comentando uma campanha de construção de banheiros externos, em domicílios que não os tinham, promovida pela prefeitura em 1987:

$O$ (...) [vereador 'A'] se elegeu com esses banheirinhos. Eles começaram a distribuir não só para quem precisava. Evidentemente, para pessoas estratégicas, líderes que tem uma certa influência na rua, cabos eleitorais e tal. E ai, o (...) [vereador 'A'] voltou então cobrando de quem tinha feito banheirinho. Caso do 'seu' (...) [cita o nome de um morador], nessa eleição da Associação de Moradores [relatada anteriormente]. Ele tinha uma certa amizade com a gente, mas tava assim chateado porque o (...) [vereador ' $A$ '] tinha feito banheirinho na casa dele. Como é que ele ia fazê, né? Então, realmente ele apelava para essa questão. Outra questão que ele apelava era essa mesmo:

- Tudo bem, você vai precisar de mim. Você vai precisar de uma escritura...

Uma outra coisa que ele trabalhava muito, era escritura de casa, de terreno." ( Ex-integrante de C.E.B. na região do bairro ' 5 ', no período $88 / 90$ e da P.O. em seguida)

Teve uma época que deu uma chuva de vento aí. $O$ (...) [o vereador ' $B$ '] ia de casa em casa, entregando telha prá cobrir. Ele é que ia lá entregar:

—Ó, tô entregando... (Ex integrante da P.J. na região do Bairro '7')

Eli Diniz sintetizou o fenômeno do clientelismo como sendo a prática do favor e a arte da sedução política. $(1982 b, p .22)$ No que diz respeito à maneira de se prestar o favor, elencou-se atrás, inúmeros exemplos. E não faltam também situações que revelam parte da estratégia utilizada pelo 'vereador do bairro' para a sedução de sua clientela. Tal

(7) Aqui, significando grupo integrado por semelhanças econômicas, culturais e religiosas, o que lhes garantiria, em tese, irmandade, coesão e relações harmônicas entre seus membros. encantamento não se assenta apenas na troca, na oferta de 'benefícios' materiais. Aparecer como 'homem daquele bairro', como 'filho da região' é artimanha que funciona bem, pois encontra acolhida numa solidificada representação ideológica do que seja 'comunidade' (7), inclusive de forte inspiração religiosa, que afeta as avaliações de boa parte daquela população inscrita no plano do clientelismo.

Além de 'pertencer' à 'comunidade', é preciso aparecer como pessoa igual aos outros moradores do bairro, ou seja, apresentar-se como homem pobre, de vestimentas simples e atitudes modestas. Importa, mesmo agora sendo um político, não distanciar-se do povo, do seu jeito, das suas maneiras.

Esse negócio do vereador de bairro, mas é forte, forte aqui em (...) [na cidade], a ponto do cara falar que mora no bairro, e não mora. Tipo o (...) [vereador ' $B$ ']. Ele é 'o vereador do (...) [bairro '3']', ele mora lá no Centro, perto do (...) [colégio da cidade], e ele é 'o vereador do (...) [bairro '3']'. É a segunda gestão dele. (Ex-diretor da Associação de Moradores do Bairro '2')

Eles não têm muita coisa. Você pode ver que o (...) [vereador ' $B$ '] anda com um fusquinha velho. Até na campanha dele, o emblema era um fusquinha daqueles 69. Então, se eles têm alguma coisa, eles têm escondido. Não aparece. (Ex-militante da P.J. na região)

$O$ (...) [vereador ' $E$ '] era um vereador, quando nós chegamos lá, em descenso, porque ele não tinha essa prática, esse pique do (...) [vereador 'A']. Ele já começou a andar de terno. Já se distanciou. $O$ (...) [vereador 'A'] não. Anda tudo sujo, prá lá e prá cá; fazendo casa, e tal." (Ex-coordenadora de C.E.Bs. na região, no período de 1989 e 1991)

Este estilo de 'política de comunidade' frisa o caráter pessoal da relação representante-representado, pela qual o vereador do bairro desenvolve vínculos primários com os moradores, como o conhecimento pessoal, a amizade, e até o compadrio. Ocorre que a interferência deste tipo de vínculo desideologiza (camufla a ideologia), despolitiza um grupo de relações sociais que são, antes de tudo, políticas. Pelo menos na sua fundamentação. ${ }^{(8)}$

No caso pesquisado, outro dado que ajuda a formar o conjunto das práticas clientelistas, é o da violência. Esta também aparece como ítem recorrente. Da mesma maneira que as práticas clientelistas inserem-se num quadro político onde a violência é componente sempre à vista, o próprio clientelismo, em particular, também se escora, todo o tempo, em atos violentos. O 'vereador do bairro', nos contatos cotidianos que monta nos bairros buscando levantar e manter o controle político de parcelas da população, demonstra não ter escrúpulos na execução dos seus (e da prefeitura) objetivos.

(8) Sobre o caráter de classe do Estado, ver SOBRINHO, mimeo. 
Esse pessoal sempre foi muito violento com a gente. Uma das coisas que o (...) [vereador 'A'] utilizava, para desqualificar nosso movimento, era falar mal das mulheres que participavam. Tinham muitas mesmo! Então, uma das coisas, era chamar a gente de vaca, mulher-à-toa, por exemplo. Eu pessoalmente já tive numa outra eleição de Associação no (...) [Bairro '8'] e ele, simplesmente enlouqueceu e:

- Essa vaca, e tal...

Os negros ele chamava de macacada. $O$ caso específico do (...) [vereador 'A'], ele era realmente muito violento, preconceituoso. E, aí as pessoas se intimidavam sim, porque ele ameaçava:

- Você vai precisar de uma escritura.

$E$, realmente, se precisasse dele e ele tivesse alguma..., algum viés com a pessoa, ah!, a pessoa não conseguia mesmo. Coisa que é direito, só que ele ia lá [na prefeitura] e barrava. Eu não conseguia aula em (...) [cita a cidade]. Passei no teste seletivo em segundo lugar. Precisei mudar para (...) [cita o nome da cidade vizinha] para conseguir.(Ex-coordenadora de C.E.B. na região do Bairro ' 1 ' e Bairro '4', no final dos anos 80. Participou de inúmeros movimentos reivindicatórios neste período)

Por exemplo, na questão do transporte coletivo. Nós fizemos quatro reunião prá tirar uma pauta de reivindicação para fazer com o (...) [proprietário da empresa prestadora do serviço na região]. Marcou na Câmara, o (...) [proprietário da empresa] veio. Daí eles [os vereadores do $P M D B$, situação na época], mudaram tudo. Chegou lá na hora, apresentaram outra pauta de reivindicação que não tinha nada a ver. Aliás, eles começaram a defender a planilha de custo do (...) [proprietário da empresa]. Inclusive dai saiu um tumulto muito grande. Uma menina do (...) [bairro '2'] foi empurrada, quebrou o óculos, e teve um tumulto grande, justamente por isso aí. (Ex-integrante da P.J. na região do Bairro '7', na segunda metade dos anos 80 )

Nesta cidade, trata-se de um clientelismo estreitamente (mas não unicamente, como já ressalvamos na introdução) vinculado à reprodução eleitoral. Tanto nos seus objetivos quanto na sua existência. Quer dizer que, é do resultado das eleições municipais que depende a definição de quem se constituirá no 'dono' deste ou daquele bairro, quem mediará o fluxo de serviços/benefícios do Estado (prefeitura), e até, provavelmente, quais lideranças do bairro terão eminência e quais perderão espaço e influência naquele período. Aqui, o clientelismo não pode ser desligado de sua eficiência eleitoral. (AVELINO FILHO, 1994, p. 231)

Em razão disso, o sistema eleitoral e os partidos políticos são peças-chave no processo aqui analisado. Para ser eleito como vereador (ou reeleger-se), pode vir a ser fundamental contar com a indicação e colaboração de alguma clientela já instalada e sob influência de algum 'vereador do bairro'. Por outro lado, ser vereador abre a perspectiva de construir sua própria área de influência, de definir uma jurisdição própria de ascendência, o que pode vir a garantir a reeleição, ou a eleição de um 'companheiro de partido', enfim, certo controle da competição política nos redutos.

O certo é que, aqueles que podem manipular boa quantidade de recursos estatais (públicos) detêm um instrumento decisivo para a estruturação e o controle de uma rede de influências, o que amplia suas chances de sobrevivência eleitoral, alargando seu cacife e prestígio social.

É considerando tal importância que as duas últimas disputas eleitorais no município foram palco de intensa luta, e mereceram, do grupo político que comanda a prefeitura, a acentuação da compra de votos e o aperto no grau de violência que usualmente utiliza, ou do qual é conivente:

Na última eleição prá prefeito aqui em (...) [cita a cidade], a polícia teve que tomar duas kombi lotada de cesta básica. Amanhã era a eleição. Hoje às $10 \mathrm{~h} 00 \mathrm{~m}$ [22h00m] eles tavam com a kombi carregada de cesta básica prá levar pro (...) [bairro 'I'] prá distribuir pro povo. Eles distribuíam à noite. (Fundador da P.J. na cidade) deputados,

$\mathrm{Na}$ última eleição para presidente da república e

(...) nos cercaro, enfiaram a camionete na frente da variant e eu parei. Desceram com um pedaço de pau desse tamanho, cercou a frente do carro. (...) recolheram nosso material [de campanha] e ameaçaram. Eles foram pagos prá fazê isso. No outro dia, os mesmos que fez isso era fiscal nas mesas de apuração. $O$ (...) [parente de um alto funcionário da administração municipal] tava junto. $O$ cara que trabalha na delegacia fazendo carteira de identidade, que eles colocaram lá, também, tava junto. $O$ motorista da camionete trabalha na prefeitura. Um outro baixinho que tava junto, trabalha na prefeitura também. Todos. Gente que eles [grupo político dominante] contrataram, barra pesada. (Ex-diretor de Associação de Moradores)

Depois de instalada a rede clientelista, mantê-la a qualquer preço torna-se imperioso, porque tais práticas têm influência certa sobre o voto de parte dos moradores. Esta influência, como já foi demonstrado, sustenta-se na relação pessoal que instala trocas constantes dos moradores com o 'vereador do bairro', mesmo que mediadas, às vezes, por alguma outra 'pessoa de influência' daquele bairro, ligada ao vereador.

Não restam dúvidas de que, para o político local, garantir uma clientela privada, mantê-la sob sua influência, revela-se de uma importância indiscutível na obtenção de votos, ou para si, ou para seus indicados. 
Pelo suposto, não se há de poupar esforços (o 'vereador do bairro', e a prefeitura), no sentido de barrar ou reduzir ao máximo as possibilidades das classes populares de construírem movimentos sociais reivindicativos (através de Associação de Moradores, ou não), de caráter autônomo e independente daquelas redes clientelistas esclarecidas anteriormente.

A escolha do período recortado para esta pesquisa, levou em consideração também que havia nesta fase, a existência de movimentos autônomos de reivindicação dos moradores, nos bairros onde se firmaram e se desenvolveram relações de clientelismo, articuladas, especialmente, pelo 'vereador do bairro'. Foram movimentos surgidos a partir de uma série de demandas que se punham:

(...) de 87 a 89, teve essa demanda do asfalto, teve uma demanda Posto de Saúde, teve uma demanda por alfabetização de adultos." (Ex-moradora do Bairro 'I', integrou C.E.Bs. e P.O. de 1987 a 1989)

O bairro sofria muito mesmo. Depois do quebraquebra [de ônibus ocorrido em 1989, no Bairro 'I'], deu até uma melhorada, mas antes a gente sofria tipo um ônibus a cada uma hora. Era muito dificil mesmo. E, uma das coisas que o pessoal tinha mais revolta era o ônibus." (Ex-integrante da P.O. da região)

(...) participávamos de movimentos por transporte coletivo, asfalto, saúde... Fazíamos sem ser nada, quer dizer, espontaneamente, à parte... Esses movimentos que a gente participava, era absolutamente autônomos em relação à prefeitura." (Fundador e ex-integrante da P.J. na cidade. Ex-diretor de Associação dos Moradores na região do Bairro ' 3 ')

Pelo lado da prefeitura e do seu mediador, o 'vereador do bairro', põe-se o esforço, num conjunto de iniciativas que buscam reduzir o espaço da política de setores das classes populares (seus movimentos, reivindicações) a espaços tutelados e subordinados. Até porque, se esse não é o objetivo imediato daquelas práticas, é, sem dúvida, o objetivo estratégico final. Seguem relatos que confirmam a intenção:

Outro fato que eles colocavam contra a gente, era na eleição das Associações de Moradores. Naquela época, se formasse uma Chapa de Associação de Moradores que não fosse do grupo deles, ou então que eles percebessem que fosse pessoal Petista mesmo, eles financiavam a outra Chapa. Dava camiseta; os vereadores deles vinha no dia e ficava fazendo campanha. $O$ (...) [vereador ' $D$ ', integrante da corrente hegemônica da prefeitura], numa eleição da Chapa no (...) [bairro '2'], ele ficou no portão do colégio pedindo voto para a outra chapa. Quando a gente ganhava era porque fazia composição com outras pessoas que não eram muito politizadas. No primeiro nós tentamos sozinhos, daí que não deu." (Ex-diretor da Associação de Moradores do Bairro '2'. Integrante da P.O. na região do Bairro ' 3 ')

A Associação de Moradores, enfim, esses movimentos populares que eles conseguiam controlar através do vereador, através das Associações, tinha um vínculo. Daí eles não tinham nenhuma autonomia. Era uma extensão da prefeitura no bairro. (Ex-integrante da C.E.B. na região do Bairro ' $I$ ', no período 87-89)

Em 1990, lideranças populares ligadas às C.E.Bs. da região do Bairro '1' e Bairro '4', organizaram-se para a disputa da direção da Associação de Moradores do Bairro '4'. Fizeram trabalho cuidadoso, cadastrando os moradores do bairro, confeccionando panfletos, utilizando-se de carro-de-som, etc. A possibilidade de ganhar aquela eleição no Bairro '4' poderia resultar numa brecha no domínio hegemônico que a prefeitura tinha sobre as Associações da região. Daí, a mesma não mediu esforços, juntamente com o 'vereador do bairro', para impedir tal possibilidade:

Era ele [o 'vereador do bairro'], ele que tomou conhecimento do nosso trabalho, da possibilidade concreta que a gente tinha de ganhar a Associação do (...) [Bairro '4']. E, ele que foi lá nas instâncias do $P M D B$ e na própria prefeitura, na Assuntos Comunitários [Secretaria de] e chamou a atenção. (Ex-integrante de C.E.Bs. na região. Fez parte da Chapa 'autônoma' que disputou a referida eleição)

$O$ (...) [vereador 'A'] fez o seguinte: quando percebeu que realmente a gente tinha feito cadastro e tudo o mais, ele começou a passar nas casas. Porque o (...) [vereador 'A'] trabalha prá caramba, de base. É um trabalho perfeito, o dele. Ele foi de casa em casa. [Moradora do Bairro ' $I$ '. Ex-integrante da P.O. no período. Colaboradora da chapa 'autônoma' na eleição em destaque)

Eles [a prefeitura] levaram um carrinho de cachorro quente, e distribuía. Fazia fila! É escola de samba! Fiquei assustada com a festa. Trocavam o voto por uma fichinha que dava direito ao cachorro quente. Houve uma situação onde o carro de som da Chapa autônoma ia à frente $e$ atrás vinha o carro do 'vereador do bairro', falando a favor da outra chapa. (Integrante da Chapa 'autônoma')

Numa perspectiva crítica verifica-se que os horizontes políticos das 'comunidades' associadas à rede clientelista montada nesta cidade tendem à resumir-se às suas necessidades mais elementares, ligadas às condições de transporte e de moradia, ao acesso à limpeza pública, ao 
direito a ter um Posto de Saúde funcionando na região. Obviamente que a centralidade destas questões também se explica pela estrutura de escassez e de carência que marca o quadro material onde se inserem e que condicionam até com certa rigidez, seu universo ideológico. (RIBEIRO, 1993)

Daí $\mathrm{a}$ disponibilidade para se sujeitarem à mobilização populista e ao apelo da política do favoritismo e de concessões parciais que, por sua vez, fortalecem a carência estrutural que alimenta a engrenagem clientelista.

Teria que ter associações de moradores independentes, que eles fizessem a reunião, discutissem a pauta de reivindicação e levasse para a Câmara.

Não. Aquele cara, vêm aqui, chega lá na Câmara, é lógico. Ele vai lá com o Projeto, é muito mais prático, do que você ir defender. Só que as pessoas acabam ficando dependente desse cara em tudo. Em tudo eles são dependentes da pessoa, e o cara adora. E eles [os moradores] aprende a não discutir nenhum problema que não seja ligado à questão local deles. Não consegue ver que o pessoal tá passando necessidade porque ganha uma miséria, não consegue ver que não tem médico no Posto de Saúde porque o sistema de saúde no Brasil tá falido. Eles não conseguem enxergar as coisas para além de (...) [cita a cidade]. Essa Associações de moradores [cooptadas] conseguem enxergar o seguinte:

- Nós vamos na prefeitura e reivindicamos.

Mas não consegue ver que o Brasil precisa ser mudado. Que eles tem que fazer reuniões no bairros para conscientizar as pessoas, discutir. Para você ver, nosso grupo aqui discute tudo, desde a Reforma Agrária, plebiscito, a questão da previdência. Tudo o que rolar lá no Congresso você pode ter certeza que o grupo ali do Bairro ' 7 ' discutiu. (Integrante da P.O. da região do Bairro '7' e Bairro '5')

Neste município, a estrutura de vínculos que envolve certas lideranças locais, os vereadores 'donos' destas áreas e a prefeitura (suas secretarias), é capaz, segundo alguns relatos, de ser funcional até certo ponto, para a região sob tutela, porque 'facilita' a vinda de recursos e serviços públicos, ao menos, em comparação com o atendimento destinado a bairros que não estão articulados a esses mecanismos. Quer dizer, o 'vereador do bairro' é capaz de agilizar 'benefícios' públicos para aquela região sob sua influência, só que, em detrimento de um outro possível padrão mais racional, mais justo até, de distribuição.

É o caso descrito abaixo, onde os entrevistados comparam a diferença de atendimento às necessidades que recebe um bairro que vem tendo (há duas gestões) o 'seu' vereador (bairro '6') e um segundo bairro (o bairro '7'), onde boa parte das lideranças comunitárias, ligadas às Pastorais da Igreja Católica (P.O., P.J.), vem há tempos resistindo ao flerte cooptativo que busca sua sujeição à forma de condução das políticas públicas que até então a Prefeitura vinha desenvolvendo. Segundo os próprios entrevistados, o 'vereador do bairro' de fato privilegia a 'sua' região justamente para garantir a reprodução do controle sobre certa clientela eleitoral, garantindo seu futuro político.

Funciona naquele método: em vez da Associação de Moradores buscar, reivindicar, o vereador traz alguns beneficios para o bairro. É através do vereador. Daí ele esquece que é vereador do município. Ele esquece do Bairro '7', esquece do... Ele lembra do bairro dele, que ele tem que se eleger novamente ali. E, isso aí, eles começaram desde a época do (...) [prefeito da época], que é onde eles escolhia, mapeava os bairros. (Ex-integrante da P.J. na cidade)

Alguns bairros ficam órfãos, porque, veja bem, são 11 vagas para vereador. Aquela região [do bairro '6', Bairro '9', Bairro '10'] tá com cinco vereadores. Alguns são ligados mais ao Centro da cidade, alguns são médicos, não são ligados a nada. Então, quer dizer que isso não funciona. Comparando com o (...) [bairro '7'], que é um dos bairros mais antigos. Mais antigo até que o Centro. Praticamente ali no (...) [bairro '7'], fora o asfalto, não foi feito nada ali. Tem rede de esgoto, algumas ruas ainda não têm. E não tem uma quadra, não tem Posto de Saúde. Problema de coleta de lixo. A melhoradinha que teve, veio de denúncia, no $I^{\circ}$ de maio [dia do trabalhador, onde as Pastorais da região organizam eventos de protesto $e$ reivindicação], da Gestão da Associação [não vinculada à Prefeitura]. (Integrante da P.O. na região do Bairro '7')

Essa mediação permite à prática personalista que adquira legitimidade junto aos atores envolvidos na rede de relações, já que, como foi dito anteriormente, aqui o atendimento às necessidades de serviços públicos básicos já não é encarado como um direito e uma prerrogativa de cidadania. Considerada neste momento, como mecanismo de manipulação política, essa prática serve justamente para perpetuar a exclusão das classes populares da arena do poder político local.

Sabe porque que é terrível essa questão do vereador de bairro. Porque não tem um vereador para cada bairro, né? Então, algumas regiões da cidade ficam esquecidas, porque você pode pegar por exemplo, por mais assistência que eles deram pr'aquela região lá [do bairro 'l'], é lógico que o pessoal lá ainda precisa de um monte de coisas, mas lá eles ainda fazem alguma coisa, aqui não faz nada. Aqui na vila, o pessoal reivindica uma cancha de esportes, prás crianças brincá e não tem. O pessoal joga bola na rua. Ali, naquela região do (...) [bairro '6'], tem sete campo de futebol, eles construíram ginásio de esportes, tem quadra... 
Quer dizer, por quê? Daí eles enfia na cabeça das pessoas assim:

- Tem que ter o vereador, viu? Lá tem vereador e lá funciona.

Mas não tem como cada bairro ter seu vereador. (Ex-diretor da Associação dos Moradores do Bairro '2')

Do ponto de vista ideológico, a maneira como se coloca a relação representante-representado dificulta a possibilidade de identificação do eleitor-sujeito com um grupo caracterizado por uma dada inserção na estrutura social, ou seja, a identidade enquanto trabalhador ou mesmo enquanto cidadão. Portanto, portador do direito de exigir providências dos poderes públicos de maneira clara (institucionalizada, prevista) e direta, sem a necessidade das mediações populistas, que pessoalizam, não só um poder, que na essência é o poder de um grupo ou de uma classe, como pessoalizam também o poder do Estado, que deixa de ser o que é: um poder estruturado que serve preferencialmente aos grupos dominantes da sociedade (SOBRINHO, 198-). Assim, o governo municipal aparece aos moradores dos bairros como uma rede de posições de poder (de um vereador, de uma liderança, de um secretário, etc.), que pode garantir que se abra a porta de benefícios de vários tipos e dessa maneira, proteger e abrigar os que lhe estão próximos.

Eu acho que o prejuizo desses vereadores, é que, quando chega o vereador, acaba. Ninguém reivindica. Ele chega, tudo é ele. Ele que faz. Ele dá o dinheiro. Ele dá passe, paga o ônibus pro pessoal ir para uma excursão. Qualquer coisa que o pessoal for fazer, eles vão atrás dos vereadores. Então, o pessoal vê os vereadores como alguém que tem dinheiro para dar para eles, prá ajudar eles. Eles não vai na Câmara. A reunião da Associação [de moradores] sempre tem um vereador junto, na reunião. As vezes até coordenando. Aqui no (...) [bairro '5'], teve uma reunião da Associação de Moradores para discutir a questão da prestação das casa. O presidente do bairro, antes de começar a reunião, ele falô:

- Passo a palavra pro (...) [vereador ' $F$ '], antes dele falar nada.

- Convidei vocês aqui e agora eu passo a palavra pro (...) [vereador ' $F$ '], (que era o vereador).

- Antes de qualquer discussão. (Integrante da P.O. na região do Bairro '7')

Uma conseqüência seguinte relacionada ao clientelismo, mediado pelo 'vereador do bairro', é o bloqueio da ação político-pedagógica inerente às práticas de organização e ação coletiva das classes populares que se criam autônomas. No caso específico, implica retardar os efeitos de transformações político-institucionais que os movimentos populares produzem, tanto no avanço da qualificação da atividade política destes movimentos, como no Estado, levando-o a incorporar, estruturando, demandas de cidadania social, valorizadas como ganhos da democracia.

Ou seja, tais práticas clientelistas tornam mais difícil a possibilidade da participação comunitária e popular conceberem-se

como um processo no qual as pessoas, como membros de grupos sociais, alcançam desenvolverse plenamente, assumindo o poder de decisão em tudo que thes diz respeito, defendendo seus interesses imediatos por intermédio de suas próprias organizações. A ação comunitária livre é uma forma de pedagogia do oprimido: ensina que a organização é uma forma de tomada do poder. (SOUZA e VIEIRA, 1984, p. 98)

Um dos entrevistados destaca essa consequiência:

Eu acho que uma das principais questões negativas disso tudo é a não politização do povo mesmo, o afastamento do povo da questão de participar mesmo da vida do bairro, da vida política, de ter informação, saber. Ter vida, entendeu? O bairro deixa de ter vida. (Ex-integrante da P.J. na cidade. Candidata a vereadora em 1992)

Há tempos a prefeitura mantém um programa de distribuição de tíquete-leite para as famílias pobres da região em torno do Bairro '7'. Ocorre que a distribuição do tíquete é realizada por uma liderança comunitária que, além desta característica, é reconhecido como um inquestionável cabo eleitoral do grupo político que comanda a gestão do município há três pleitos. Inclusive a distribuição é realizada a partir da casa desta liderança. Tal prática é tipicamente clientelista, e aqui conta com a mediação do preposto no bairro: um cabo eleitoral fiel, que certamente não deixará de lembrar ao pobre que vem em busca do leite, que este é 'doação' da prefeitura, e favor seu. O débito está instalado, junto à humilhação e à perda de dignidade. Veja-se o comentário que segue:

Então, as pessoas não crescem. Como você vai crescer, se aquela pessoa tá te dando o saquinho de leite. Se fosse uma coisa diferente; pela Associação de Moradores. Você não pode comprar, mas você pegou um tíquete, e durante o mês você ia na mercearia como qualquer outra pessoa, passasse pelo caixa e entregasse aquele papelzinho, você tinha dignidade. Mas da forma que era feito, era tipo assim, para ganhar voto. Fica de favor, as pessoas não crescem, ficam dependentes daquilo. Acha que quem tá dando tá.... (Ex-integrante da P.O. na região do Bairro '1')

Efetivamente, o que há é uma obstrução de possíveis canais efetivos de participação. $\mathrm{Na}$ verdade, aqui, esta não passa de uma farsa. Ela é cultivada, enquanto e porque, não é livre, autônoma. O governo local teme cercar-se pela cidadania organizada. (DEMO, 1990) 
E a gente, desde o começo lá, por ser uma oposição, a gente não teve da questão da prefeitura, nós não tivemos espaço nenhum. Isso não foi, de jeito nenhum, dado à gente. (...) Eles não iam receber mesmo que fosse um outro. Não. Eles anulavam mesmo. Ignoravam.. (Ex-moradora do bairro '1'. Integrante de C.E.B. na região, no período de 1988 a 1991)

\section{CONCLUSÃO}

O surgimento dos novos movimentos sociais no Brasil (a partir da década de 70) está ligado à tentativa de setores das classes populares de estabelecerem

um novo equilibrio de forças entre Estado (aqui entendido como o campo da política institucional: do governo, dos partidos e dos aparelhos burocráticos de dominação) e sociedade civil (campo da organização social que se realiza a partir das classes sociais ou de todas as outras espécies de agrupamentos sociais fora do Estado enquanto aparelho), bem como no interior da própria sociedade civil nas relações de força entre dominantes e dominados, entre subordinantes $e$ subordinados. (SCHERER-WARREN, 1993, p. 50)

No entanto, seus intentos precisam ser relativizados por inúmeras razões. (ORTIZ, 1995, p. 65-9) Uma delas é o fato de que, no Brasil, ainda sobrevive uma formação histórica que se constrói reapresentando, permanentemente, relações sociais autoritárias e conservadoras, tanto no plano da política institucional, como no da sociedade civil.

$\mathrm{E}$, a reprodução dessas características, é como um vento forte que empurra no sentido contrário às tentativas dos novos movimentos socias de corroer as formas autoritárias e excludentes que as elites políticas no poder impingem ao Estado. Inclusive e especialmente aos governos locais.

No ir e vir desses movimentos sociais, principalmente os das classes populares, nas suas conquistas e frustrações, eles se debatem com um Estado que não aguarda passivo, sua superação, sua reforma. Os grupos políticos incrustrados nos seus aparelhos, ou reeditam antigas formas de cooptação e controle pela violência, ou não se furtam a 'inventar' novos mecanismos de dominação, que podem vir a incluir um clientelismo moderno, mesclado ao participacionismo e à institucionalização.

Já se alertou, na introdução a este texto, que há outros elementos que dificultam a construção de um Estado no Brasil que se constitua incluindo a cidadania organizada. Inclusive obstáculos culturais e ideológicos de relevância. Mas, esta pesquisa tratou de um caso de domínio político local, cujos autoritarismo, burocratismo e caráter não-popular do Estado derivam, resultam do agir deliberado das elites políticas daquela cidade.

É sob sua iniciativa que se constrói um quadro institucional: a) burocrático, que não colabora na criação de canais formais, institucionalizados, de participação e representação dos interesses das classes populares; b) cooptador e autoritário, que busca a todo o tempo tutelar as organizações coletivas dos setores populares da cidade, restringindo sua liberdade e autonomia.

É ainda sob seu patrocínio que se instala um conjunto de práticas políticas tipicamente clientelistas, onde o ator principal que as organiza é o 'vereador do bairro'. Um personagem que monta seu mando político em determinados bairros do município, a partir de redes de influência que ele tece e consolida, distribuindo como favor e dádiva, recursos e serviços públicos. O que acaba despolitizando as relações das classes populares com o Estado e 'politizando' relações pessoais, como as de amizade e compadrio, transmutadas em recursos didáticos para uma 'boa' dominação política sobre os pobres.

Aqui, o Estado 'doador' e tutelador dos movimentos das classes populares gera, entre os membros desta, a subserviência, enquanto obstaculiza sua auto-organização, brecando seu desenvolvimento político-pedagógico. Da mesma forma, amortece os conflitos sociais, filtrando as lideranças e as demandas surgidas em razão de contradições que são na verdade estruturais.

No Brasil, a subserviência e a exclusão das classes populares da participação política real, é

sobretudo imposição histórica, [que] vem alimentada através dos séculos por politicas interventoras, pela presença avassaladora de lideranças centralistas, pela prepotência de quem tem dinheiro e poder (DEMO, 1990, p. 97),

e perpetuadas por elites políticas locais que se inspiram na velha tradição política brasileira (elitista, autoritária e excludente), tratando essa tradição não como velhice, mas como 'juventude acumulada', de onde tiram inspiração para reeditar, modernizando, antigas formas de domínio sobre as classes populares, sustentando um status quo extremamente desfavorável a estas classes.

\section{REFERÊNCIAS BIBLIOGRÁFICAS}

AVELINO FILHO, George. Clientelismo e política no Brasil. Revisitando velhos problemas. Novos Estudos, São Paulo, n 38, p. 125-240, mar. 1994.

CARDOSO, Franci Gomes. Organização das classes subalternas: um desafio para o Serviço Social. São Paulo: Cortez/Ed. da UFMA, 1995.

CHAỨ, Marilena de Souza. Cultura e democracia. São Paulo: Cortez, 1989. 
COHEN, Bruce. Pesquisa sociológica e áreas de especialização. Sociologia Geral. São Paulo: McgrawHill, 1980.

Da MATTA, Roberto. Em torno do autoritarismo político e social: reflexões, dúvidas, indagações. Educação e Sociedade, Campinas, ano XVI, n 53/especial, p. 675693, dez. 1995.

DEMO, Pedro. Pobreza política. São Paulo: Cortez, 1990.

DINIZ, Eli. Voto e máquina política: patronagem e clientelismo no Rio de Janeiro. Rio de Janeiro: Paz e Terra, 1982a.

Clientelismo urbano: ressuscitando um antigo fantasma? Novos Estudos, São Paulo, Vol. 1, n 4, p. 2126 , nov. 1982 b.

DROULERS, Clientelismo e emprego público. Sociedade e Estado, Brasília, vol. 4, pg. 126-44, jan./jun. 1989.

DURHAM, Eunice R. Movimentos sociais: a construção da cidadania. Novos Estudos, São Paulo, nº 10, out. 1984.

FISCHER, Tânia. O poder local no Brasil: temas de pesquisas e desafios da transição. Revista de Administração pública. Rio de Janeiro, p. 86-93, abr./jun. 1991.

HOLANDA, Sérgio Buarque de. Raízes do Brasil. Rio de Janeiro: José Olympio, 1988.

JACOBI, Pedro R. Movimentos sociais urbanos no Brasil: reflexão sobre literatura nos anos 70 e 80 . BIBANPOCS, Rio de Janeiro, n 23, p. 18-24, $1^{\circ}$ sem. 1987.

Movimentos sociais urbanos: os desafios da construção da cidadania. Cadernos dos CEAS, Salvador, p. 34-43, set./out. 1990.

JACOBI, Pedro R. Prefeituras democráticas, movimentos populares e poder local: participação, cooptação ou autonomia? Espaço \& Debates, São Paulo, n 9, p. 6669, ago. 1983.

LEAL, Victor Nunes. Coronelismo, enxada e voto: o município e o regime representativo no Brasil. São Paulo: AlfaÔmega, 1975.

LEDRUT, Raymond. Política urbana e poder local. Espaço \& Debates, São Paulo, n³, p. 5-21, set. 1981.

LINHARES, Maria Yedda (Org.). História Geral do Brasil. $6^{a}$ ed. atualizada. Rio de Janeiro: Campus, 1996.
NOVARO, Marcos. O debate contemporâneo sobre a representação política. Novos Estudos. São Paulo, $\mathrm{n}^{\circ}$ 24, jul. 1995.

ORTIZ, Renato. A construção de uma nova cultura política. In: VILLAS-BÔAS, Renata; TELLES, Vera.Poder local, participação popular e construção da cidadania. Fórum Nacional de Participação Popular nas Administrações Municipais. São Paulo: Instituto Pólis, 1995.

OTTMAN, Götz. Movimentos sociais urbanos e democracia no Brasil: uma abordagem cognitiva. Novos Estudos. São Paulo, n 41, p.186-207, 1995.

PAOLI, Maria Célia. Movimentos Sociais: Cidadania e espaço público - anos 90 . Humanidades. Brasília, v. $8, n^{\circ} 4$, p. 498-504, 1992.

RIBEIRO, Maria Thereza Rosa. Um enfoque teórico sobre movimentos sociais urbanos. Cadernos do Instituto de Sociologia Política da Universidade Federal de Pelotas. Pelotas, n5, p. 49-57, 1993.

SADER, Emir (org.). Movimentos sociais na transição democrática. São Paulo: Cortez, 1987.

SCHERER-WARREN, Ise. Redes de movimentos sociais. São Paulo:Cortez; Maranhão: Editora da Universidade Federal do Maranhão, 1993.

SOBRINHO, Pedro V. Costa. As reflexões de Marx sobre o Estado no Livro I de 'O Capital'. Novos Rumos. São Paulo, s.n., s.1., 198-, mimeo.

SOUZA, Ailton Benedito de Souza; VIEIRA, Amaral Vieira. Poluição, alienação e ideologia. Rio de Janeiro: Achiamé, 1984.

ZALUAR, Alba. Carnaval e clientelismo político. Cadernos CERU, São Paulo, $2^{a}$ série, nº 1, p. 36-64, 1985 b.

A máquina e a revolta: as organizações populares e o significado da pobreza. São Paulo: Brasiliense, 1985a. 